\title{
Names and Reality in Mao Zedong's Political Discourse on Intellectuals
}

\section{Maurizio Marinelli}

\section{(2) OpenEdition}

\section{Journals}

\section{Electronic version}

URL: http://journals.openedition.org/transtexts/268

DOI: $10.4000 /$ transtexts.268

ISSN: 2105-2549

\section{Publisher}

Gregory B. Lee

\section{Printed version}

Date of publication: 1 June 2009

ISSN: 1771-2084

\section{Electronic reference}

Maurizio Marinelli, « Names and Reality in Mao Zedong's Political Discourse on Intellectuals », Transtext(e)s Transcultures 跨文本跨文化 [Online], 5 | 2009, document 5, Online since 03 April 2010, connection on 19 April 2019. URL : http://journals.openedition.org/transtexts/268 ; DOI : 10.4000/ transtexts. 268 


\title{
Transtext(e)s Transcultures 跨文本跨文化
}

Journal of Global Cultural Studies

5 | 2009:

Varia

(Re)Inventing "Realities" in China

\section{Names and Reality in Mao Zedong's Political Discourse on Intellectuals}

\author{
MAURIZIO MARINELLI
}

\section{Résumé}

This essay addresses the topic of the political use of formalized language. In the Chinese historical tradition the 'correctness' of language has always been considered a source of moral authority, official legitimacy and political stability. Political language has always had an intrinsic instrumental value, since its control is the most suitable way to express and convey the orthodox State ideology. Formalized language has also served as a device to standardize the range of expressiveness of Chinese intellectuals.

Wittgenstein argues that words have the power to set the limit for the 'expression of thoughts', because the boundaries of language indicate the boundaries of one's own world. My focus is on specific forms of power embodied in language practices and discursive formations recognizable in selected texts. This inquiry illuminates various possibilities for normalization and inculcation of formalized language. The internal constitution of selected texts is examined with an eye to the dialogic interaction with the production and reception of Mao's and post-Mao's political discourses on intellectuals. Analysis of 
language formation and use in a comparative perspective considers the socio-historical contexts and reveals a pattern of evolution, involution, and finally devolution of language.

\section{Texte intégral}

\section{The legacy of Confucius: 'What is necessary is to rectify the names' (必也正 名)}

The term evolution indicates a process of continuous change: it alludes to the process in which the whole universe is a progression of interrelated phenomena. It intrinsically carries a positive connotation, suggesting a development, a deepening or a growth. ${ }^{2}$ For the purpose of this study, this term refers to the evolution of a specific relation between language, the representation of reality and the art of governing, since this article analyses contemporary political language within the framework of Confucian epistemology ${ }^{3}$, which was based on the zhengming (正名) theory.

From a semantic perspective, the compound rd 正名 [usually translated as 'rectification of names' but preferably as '(creation of the) correct names'] contains the character 正, which can function bothasa verb --meaning to rectify, to correct (as in the compound words 端正, 改正, 糾正)-- and as an adjective --meaning correct, right, but also formal or official (as in the compound words 正規,正常,正式). From an etymological perspective, this character literally means 'to stop' 止 'at the line' - : 正 is therefore associated with the creation of orthodoxy.

The character 正is also a constituent part of three policy-related characters. The first is zheng 政, which as a Verb means to govern [literally: correct (phonetics) + striking (semantic component)] and as a Noun, indicates the government or administration. The second character is zheng整, which as a Verb means to put in order or rectify, and as an Adjective: proper, in good order. 整 was used, for example, in 1942 at the launching of the 'rectification movement' (zhengfeng yundong整风运动). The third character is cheng惩, which means to punish or punishment. In the evolution of the 正名 theory, 正 has a clear association with the art of governing (政). Therefore, 正名 can be interpreted as a politically connotated mechanism aimed at creating a prescriptive order of things (整), which responds to a sort of imposed and self-imposed regulatory practice (惩). The possible range of expression of reality via language is confined within the perimeter strategically defined by the epistemological limit of 'stopping at the line'.

Beginning with ancient China, language has always played a crucial role in the 
construction of a virtual symbolic order and a claimed socio-political reality. ${ }^{4}$

According to Confucius an extremely precise relationship exists between the notion of 'correctness' (正), as expressed in the theory of 'correct names', and the art of governing the State (政). Confucius stated: 'If names are not correct, the saying is not in accordance with the truth of things. If the saying is not in accordance with the truth of things, affairs (of the State) cannot be carried on with success (ming bu zheng ze yan bushun, yan bushun ze shibucheng名不正则言不顺，言不顺则事不成). 5 Confucius meant that names, and therefore language, embody norms and have a performative function ${ }^{6}$ : the art of governing the State is based on the axiomatic principle of giving correct names to things and acting accordingly. This is one of the fundamental ideas of his political theory: Confucius argued that a good government is obtained only when all the relative duties, defined by their names, are maintained. This is the 'real' meaning of 正, in the sense of 'stopping at the line'. This is thereason why, when one of his disciples asked: 'What does it mean to govern?' Confucius gave a univocally clear answer: 'To govern means to rectify the names (zhengzhi, zhengye政者, 正也). If you lead the people by being rectified yourself, who will not be rectified?'7

A crucial political strategy is to lead by correct example. Confucius argued also that a ruler able to 'rectify names', could set a clear example for his subjects to follow. When the ruler's behaviour was in line with the standards defined by his words, the ruler was thought to literally embody codes of proper social behaviour. Conversely, when the behaviour of either ruler or ruled was out of line with the idealized standards ascribed to their social position, the prerogatives that normally attended that position no longer held. A king who misruled was no longer a proper 'king', and could be legitimately overthrown and replaced. Confucian rhetoric propounded a vertically structured social and ethical hierarchy, and the 'rectification of names' played a crucial role in mediating the movement between written ideal and social practice.

7 Keeping in mind the range of significance of the character 正, I believe that the interrelation between the triad of 'correct name (ming名) - saying (yan 言) - actuality (shi 实)' on the one hand, and politics on the other, is an epistemological paradigm extremely useful in analyzing language and political discourse in contemporary China. Yan is particularly important since it refers to the codified sayings or propositions, which are connecting elements between the names and the claimed reality, and contribute to the setting of the line which cannot be crossed.

During Mao Zedong's era the 'correct names' theory was fully implemented through the mechanism of vertical propaganda. A logocentric model of representation of a claimed reality was fully enforced through the definition of a common set of rules and conventions shared by the speaker and the listener. These rules were pervasive, to the point where they became encoded in the patterns, style, syntagmatic bonds and lexical items typical of formalized language. Speech followed the expressive devices of regulated discursive 
formations: inculcated from top-down it carried an intrinsic performative power. The linguistic behaviour and metalinguistic acts of the individuals were supposed to operate in the ways required of him, according to a criterion of formal correctness based on the 'harmony' between the name (ming) and a claimed reality (shi) via the saying (yan).

The second dialectical term that I employ in my analysis is involution, which literally indicates the action of enfolding or entangling something. One can think of it literally as folding one thing inside another. Involution alludes to the change of shape or degree, usually implying a move from higher to lower, but in mathematics, for example, it also means exponentiation, indicating the process of raising a quantity to some assigned power. The range of significance of involution is particularly broad, since it could also mean engagement, involvement, participation, indicating the act of sharing in the activities of a group. Generally speaking, the idea of involution is associated with the concept of elaborateness, elaboration, intricacy, or abstraction, as something which is marked by elaborately complex details. In linguistics, the term involution refers to a long and complicated grammatical construction, characterised by the insertion of clauses between subject and predicate. But involution in medical science indicates either the reduction in size of an organ or part, or the regressive alterations of a body or its parts characteristic of the aging process. Therefore, the term involution is used in different contexts to indicate a more complicated scenario compared to a pre-existing one.

In this case, I use the term involution associated with evolution, to address the topic of the political use of formalised language in socialist China. I argue that what occurred after 1942 is a process of exponentiation, a sort of inward curvature or penetration of politics into common language and, progressively, a symbiotic relation between language and politics.

The last term that I employ is devolution: from the Latin devolutus, it is the past participle of the verb devolvere which means 'to roll downward' or 'to fall'. Devolution is often used in the context of social and political sciences to refer to group action, social and political control, management and direction. It implies the idea of a transfer of authority or duties to a subordinate or substitute, and indicates a process of passing down power from a central entity to local units, through successive stages. In biological science this term assumes a derogatory connotation, becoming a synonym of degeneration. Here I use devolution to refer to the post-Mao era, when one sees the struggle for survival of a certain kind of political language, along with the progressive and increasing emergence of subjective forms of expression.

Through the textual, structural, and lexical analysis of selected documents, it becomes evident how the use of the set of paradigms evolution-involution-devolution does not intend to produce a deterministic interpretation, but rather to trace the parable of the relation between political language, power and constructed reality throughout an extended period of time. 


\section{The use of words}

A crucial question in the study of political language is: What is language? A common answer is that language is a system of representation of reality. Steven Pinker associates the origin of language with instinctual nature since language is 'so tightly woven into human experience that it is scarcely possible to imagine life without it'. ${ }^{8}$ But when one considers the process of learning a foreign language, one discovers another element: a person memorizes single words and learns how to arrange certain patterns of words, compounded into sequences, but in order to be able to speak that language, one needs to learn how those strings of sounds have to be used. Pierre Bourdieu argues that language itself is a socio-historical phenomenon, which tends to exemplify the correct message and institutionalize specific social processes. ${ }^{9}$

Formalized political language is a code, which might appear to contain elements of foreignness or exclusivity, but intrinsically embodies the status of theoretical authority: it needs to be learnt and reproduced by the initiates.

Ludwig Wittgenstein points out that it is necessary to 'Let the use of words teach you their significance'. ${ }^{10}$ This means to make language itself speak because the meaning of a word derives from how that particular word is used. According to Wittgenstein, 'A picture is a fact'; in the sense that a picture also includes a pictorial relationship with the real thing, which is what makes it into a picture. He continues his inductive reasoning by aphorisms, explaining that: 'The pictorial relationship consists in the correlations of the picture's elements with things' ${ }^{11}$, and these correlations are, as it were, the feelers of the picture's elements, with which the picture touches reality. Therefore, Wittgenstein's conclusive conceptualisation of the relation between language and reality is epitomized as follows: 'Objects can only be named. Signs are their representatives. I can only speak about them: I cannot put them into words. Propositions can only say how things are, not what they are.' 12

When one considers both the intrinsic imagist power of Chinese language and the Confucian emphasis on the importance of finding 'correct names' for the art of governing, one might be tempted to apply Wittgenstein's argument on the interrelation between language and reality to the Chinese context. To proceed in that direction means to adopt an epistemological approach to language politics and to analyze the Chinese constructs of name-propositions and reality to shed light on the complex dynamics of political discourse. This can only occur within the conceptual framework of a long term historical perspective.

Wittgenstein's idea of letting the use of words speak permeates my work, which focuses on the analysis of the main characteristics of crucial political documents that define the Chinese Communist Party (CCP) policy towards the intellectuals during three distinct historical phases: the Yan'an period, the beginning of the post-Mao era, and the 1990s, respectively. In this article I focus on the characteristics of Mao Zedong's political 
language, analyzing his 'Speeches at the Yan'an Forum on Literature and Art (Zai Yan'an wenyi zuotanhuishangde jianghua在延安文艺座谈会上的讲话)', delivered on 2 and 23 May 1942, respectively. ${ }^{13}$ I compare Mao Zedong's and Deng Xiaoping's political language, using Deng Xiaoping's 13 October 1979 'Greeting words to the Fourth Congress of Chinese literary and art workers (Zai Zhongguo wenxueyishu gongzuozhe disici daibiaodahuishang de zhuci在中国文学艺术工作者代表大会上的祝辞)'. ${ }^{14}$ In examining these documents, I concentrate on the stylistic and expressive patterns to shed light on the main features of the form of 'Mao Zedong system ofthought(sixiang思想)' and 'Deng Xiaoping theory(lilun理论)'. My final aim is to reveal the elements of symmetry and asymmetry, the lines of convergence and divergence, and show the evolutionaryinvolutionary curve.

\section{The historical context of Mao's and Deng's speeches}

The Yan'an Speeches were given by Mao Zedong in the middle of the 'rectification movement', which engaged the Party for three years, from the enlarged meeting of the Politburo held on September 1941 until 1944.

The official interpretation of this movement is epitomized as follows: 'The content of the rectification movement is to oppose subjectivism byrectifying the style of study, to oppose factionalism by rectifying the style of the Party, to oppose the stereotyped Party jargon by rectifying the style of writing (fandui dangbagu yi zhengdun wenfeng反对党八股以整顿文 风). ${ }^{15}$

The third major reason for launching the rectification concerns the form. The expression 'dang bagu'(stereotyped Party jargon) indicates a problematic continuity with the past: it implies a kind of symmetry between the 'eight-part essay' (baguwen八股文) and the CCP style of writing (wenfeng文风). The baguwen, the literary composition prescribed for the imperial civil service examination, was known for the rigidity of form and poverty of ideas. The association between baguwen and dangbagu(党八股)indicates that the problem of language was part of the political and intellectual discourses at Yan'an. The character feng (wind风) in the compound word wenfeng (文风style of writing) has a clear political connotation and refers to the correct style set by the Party line. The idea of wenfeng has no dialectical power and paves the path for the progressive definition of 'Mao's style' (Maowenti毛文体), in antithesis to the aspirations of many intellectuals who joined the $\mathrm{CCP}$ at Yan'an, but not necessarily to act as 'docile bodies'. ${ }^{16}$

In Yan'an, the definition of a common and coherent Party policy program and the adherence to orthodoxy (both ideologically and stylistically) became Mao's fundamental goals: they represented the sine qua non both for the unification of the whole country 
under the CCP's rule, and the affirmation of his own personal power. Yan'an is the supreme moment in the formation of what Apter and Saich poignantly defined 'a self-sufficient world of language, signs, and symbols into which only the initiated can belong'17: Mao used all the potentiality of Chinese language together with powerful metaphors and metonymies to 'create a code out of elements of a semiology that enables the narrative to endow gesture, acts, dress, dwelling, and above all, language and literacy with the power of signifiers, while the teleology arranges the signifieds within a revolutionary frame. ${ }^{18}$ The Yan'an speeches reveal a claimed correspondence between the signifiers and the signifieds. Yan'an is the benchmark in defining a style that exhibits the way in which grammatical resources, built into Chinese language, are used as tools of empowerment. By grammatical resources, I refer to the following features and characteristics that are so effectively incorporated in Mao's speeches:

- - Analytic nature of the language, which permits terseness, but can also create generalization or ambiguity;

- - Symmetrical paratactic order, characterized by the coordination of clauses and phrases without use of connectors/modifiers;

- - Repetition of the same lexical items and structural parallelism;

- - Absence of relative pronouns and tendency to coordination;

- - Use of modal verbs and $b a$ (把) forms.

Thirty-seven years later, in October 1979, in a completely changed historical context, Deng Xiaoping delivered his speech at the Fourth Congress of Chinese literary and art workers, exactly ten months after the program for the 'four modernizations' (agriculture, industry, science and technology, defence) had been launched and ratified during the Third Plenum of the Eleventh Central Committee of the CCP (18-22 December 1978). Deng's speech set the scope of the 'opening' in the cultural sphere, demonstrating the willingness to rehabilitate the intellectuals in order to gain their support for the new policy of the Party while, at the same time, showing the unacceptability of the requests raised during the movement for the so called 'fifth modernization' (e.g. democracy). ${ }^{19}$

Mao's and Deng's speeches are lucid examples of vertical propaganda, since they aim de facto at convincing the receivers to carry out directives derived from the top leaders. One of the main features of political discourse in authoritarian regimes is the action of the propaganda apparatus, which via language sets out the orthodox behavioural guidelines from the top, mobilizing the masses and directing their deeds to emulate specific models of orthoproxy or sanctioned behaviour. Jacques Ellul argues that: 'Vertical propaganda uses all technical methods of centralized mass communication; it envelops a mass of individuals; but those who practice it are on the outside'. ${ }^{20}$ This is particularly true in Mao's and Deng's cases, even though Mao's language seems to convey the idea of a closer relation with a claimed reality. The 'truth' of the words set forth in Mao's speeches seems 
to be unassailable and definitive, thanks to the use of three major devices: direct examples from his personal experience raised as a model for emulation, the use of 'questions and answers' format, and rhetorical devices.

From a pragmalinguistic perspective, vertical propaganda requires the propagandist to have clearly formulated in his mind what should be the expected outcome and the propagandee to have a pre-desired response. The speaker uses language as an instrument in the socio-political construction of reality ${ }^{21}$, and directs the receiver's actions towards a sanctioned behaviour. The ultimate reason why the speaker uses a precisely codified language, by means of conventional and fixed expressive patterns, lies in his intention to set, via the language, the limits beyond which the audience is forbidden to go. Wittgenstein argues that words and sentences have the power of setting a limit to the 'expression of thoughts' since the limits of language indicate and set the boundaries of one's own world. Wittgenstein concludes: 'It will therefore only be in language that the limit can be set, and what lies on the other side of the limit will simply be nonsense'. ${ }^{22}$ The maximum ability of the speaker is demonstrated when taboo expressions have no possibility of being realized in thought, because a sense of self-censorship prevails in the receiver. When vertical propaganda is effective it creates a habitus ${ }^{23}$, which defines the receiver's range of expressivity, based on the discriminatory recognition of what is correct (zheng) and therefore good, and what is not. Since our symbolic world is consubstantial with our beings, the process of speaking presupposes a common understanding and aims at the assimilation of what is communicated via language. We 'are' language and our perception of the world is shaped by the structure of our particular language and by how we are told. As Martin Heidegger clarified in his analysis of the historically contingent nature of language: 'Language speaks man' rather than 'Man speaks language'. ${ }^{24}$ Language is not a universal medium which is gradually taking on the true shape of the world or true self: language is a social construct. We are 'being-in-the world', in the sense that we, as human beings living in the world are constituted by the use of the words. These words are organized according to specific sentence patterns, based on a precise grammar style, in a way suitable to encode an important ideological content. These words carry powerful social meaning, and have direct social effects.

\section{The receiving side}

The titles of Mao's and Deng's speeches immediately reveal a difference of tone. Although none of them is directly addressed to the 'intellectuals' (zhishifenzi知识分子), in his 'greeting words' (zhuci祝辞) Deng directly refers to 'the workers of the literary and artistic field' (wenxue yishu gongzuozhe文学艺术工作者), which is more personalized than the term 'Forum on Literature and Art' (wenyi gongzuotanhui文艺工作谈会) used by Mao. 
In Mao's case, the title indicates a political event, rather than addressing the alleged subject or receiver of the speeches.

Examining the opening of the two texts, a major feature of vertical propaganda becomes evident: a strong imperative connotation is implicit both in the exhortative tone of 'Comrades!' (Tongzhimen!同志们) used by Mao, and in the more formal 'Dear representatives and comrades' (Gewei daibiao, gewei tongzhimen各位代表, 各位同志们) used by Deng.

The emphasis on the 'enlarged masses' (dazhong大众), the repetitions and the exhortative tone, associated with the continuous use of first person plural pronoun 'we' (women我们) indicate both a highly excited tone and an all-inclusive function. Benedict Anderson in his work on 'imagined communities' argues that the language of the nation is intrinsically inclusive. ${ }^{25} \mathrm{~A}$ typical feature of Mao's political language is the use of a plural pronoun subject [even when the subject seems to be a hypothetical 'you' (nimen你们)]. This is as a strategic choice, since the first person plural pronoun 'we' creates a sense of inclusiveness among the receivers ('you'), and confers legitimacy to the subject's positioning and acting. The use of 'we' reveals a strong symbolic capital: it is the epitome of collective emotional universe and implicitly indicates the majority of the people. 'We' ideally refers to 'the masses' but practically to the Party, which is its representative and beholds the correct (正) standpoint: the only one that has political (政) legitimacy.

In Chinese political language, the use of 'we' creates an antagonism with the others: those who are not right and are usually objectified as 'a small number' (shaobufen'少部分) or 'a tiny minority' (shaoshuren少数人). The ambiguous expression 'shaoshuren' is a rhetoric trope, which carries a veiled derogatory connotation and, especially in the post-Mao era, has often been used as a substitute for what, in Mao's style, was identified as 'enemy' (diren敌人). Shaoshuren became a codified epitaph to indicate those individuals who are ostracized from the ideal community of 'the people' (renmin人民) and excluded as 'non-people' (feirenmin非人民) or, by inference, as 'counter-revolutionary elements' (fangemingfenzi反革命分子) ${ }^{26}$, because they are not in accordance with the 'mandate of the Party' (dangxing党性) ${ }^{27}$. The Party is the alleged embodiment of correctness and the representative of the will of the people.

The 'you' (nimen) is almost absent from these speeches, and therefore the 'we' (women) refers to the receivers, allegedly the intellectuals. But in Mao's speeches, the word intellectuals (zhishifenzi) always carries a derogatory connotation. In his speeches, the intellectuals are termed 'wenyi gongzuozhe' (文艺工作者: workers engaged in the fields of literature and art). Deng Xiaoping tends to use the term zhishifenzi more often than Mao,but it is only with Jiang Zemin that the term zhishifenzi becomes predominant and positively connotated, although fundamentally restricted to the scientists. ${ }^{28}$

Who are the receivers of Mao's speeches then? The ideal receivers of the speeches are the cadres in charge of cultural political matters, and the establishment intellectuals ${ }^{29}$ 
willing to 'serve' the revolution and the people; in other words, those who are entrusted with carrying out the political guidelines set by the Party. Therefore, the first person plural pronoun 'we' conceals and implicitly includes a second plural pronoun (nimen), and implies a profound sense of authority and appropriation: 'we' refers to the leading officials at the top of the Party hierarchy, and these leaders are urging 'you'- the subordinate receiver, to take an active part in the implementation of Party's policies and directives. 'We' is the subject of propaganda, as it serves to hide the distance and mystify the implicit hierarchical order between the speaker and the receiver. 'We' is the ideal subject-pronoun of political correctness as defined by the Party, while 'I' is the subject-pronoun of free stand, individual spirit, and alludes to free literary creation. ${ }^{30}$ ' $\mathrm{We}$ ' is the most suitable subject for a system based on the political cliché of the Party culture, whose main features are the presumptions of 'one and single public opinion' (yulun yilu與论一路) and, more figuratively, of the arbitrary existence of 'one sentence/voice chamber' (yiyantang一言堂). This second expression seems to carry a sort of Confucian resonance: yiyantang, which I would translate as 'one person says', is strictly related to the expression yanzhiyouli一言堂 (what one says is correct). In this sense yiyantang implies that only one kind of discourse is recognized as correct (zheng).

\section{Political language as performative}

Both in Mao and Deng's eras, official language upheld the 'one person says' (yiyantang) axiom, although camouflaging its imperative style with an exhortative tone and metonym rhetoric tropes. Aristotle argued that the function of rhetoric in political discourse is the art of persuasion. ${ }^{31}$ The act of naming per se is profoundly rhetorical, and rhetoric is meant to teach the audience how to think and see the world in these terms (and not in those). Both the speaker and the receiver live in the world, in this world which has a certain history or anti-history. They share a claimed vision of reality through a certain symbolic universe, which is characterized by common signs transcribed in a certain text.

I suggest linking the Aristotelian hermeneutics of rhetoric to Austin's paradigm of performative utterances. ${ }^{32}$ The key-phrases of Mao's political texts have the property of combining utterance and performance. The frequent use of $b a$ particle and modal verbs infuses in the key sentences a pragmatic force and a strong performative character as if, in the English translation, we were almost forced to use the form: 'Let us act in order to achieve a certain result.'

These texts originated as oral speeches and show the characteristics of indirect speech acts, in which one illocutionary force is performed indirectly by way of performing another. ${ }^{33}$ The pragmatic approach is particularly suitable in this case: one cannot assume a relation of equivalence between linguistic forms and communicative functions. We all 
know that there are many ways of giving simple commands (such as 'Close the door'). From a pragmatic point of view, commands are not uniquely expressed by means of imperative sentences and questions with interrogative sentences. In Chinese, commands can be formulated using the $b a$ form, which emphasizes the object and exhorts the receiver to achieve a certain result. Mao's speeches reveal a recurrent use of rhetorical questions associated with exhortations and commands.

Mao's attention to the logic consequentiality of the various parts of his discourse relies on the relation between the correct names (ming) and a claimed reality (shi). The first paragraph of Mao's initial speech at Yan'an contains what can be enucleated and recognized as the aim of the whole speech: the definition of 'the correct (zhengque正确) development of the revolutionary literature and art.' This expression refers to the imperative of linking together revolution (geming 革命) with literature and art (wenyi文艺). Mao's agenda was strongly influenced by the current situation of war and the necessity of gaining support from the intellectuals, seen as 'docile bodies', for the diffusion of the 'Yan'an spirit'. Therefore, literature and art cannot be independent creative domains or goals in themselves: they are political tools within a conceptual framework of politics wherein the 'political power grows out of the barrel of a gun'. ${ }^{34}$ Military wording is a major characteristic of Mao's language; literature and art are conceived as military weapons in the revolutionary war, as clearly revealed by Mao's reference to 'thetwo battlefronts of culture and military' (wenwu liangge zhanxian文武两个战线), and his portrayal of the intellectuals as soldiers: 'the troops of literature and art' (wenyi duiwu文艺队伍).

In the second and third paragraphs, Mao analyzes the 'question of the (intellectual) work' (gongzuo de wenti工作的问题), and uses the sentence pattern jiushi/zhe jiushi就是/ 这就是, to firmly state the logical relationof the various elementswithin the text. Again, when he analyses 'the question of standpoint' (lichang de wenti立场的问题) he uses the structural pattern jiuyao就要.... ye yao也要.......yejiushi也就是: these deixis infuse a strong pragmatic force in an oral speech. ${ }^{35}$

In the second paragraph, Mao also emphasizes that the final goal is to use art and literature as military weapons to 'emancipate the mind' (jiefang sixiang解放思想). This four-character compound phrase was coined by Mao Zedong, but it has been extensively reutilized by Deng Xiaoping after 1978: it represents a codified expression, concealing exactly the opposite semantic paradigm, since it does not refer to the freedom (ziyou自由) of the intellectuals, but to their ideal alignment with the Party line. In the following paragraphs of Mao's 'Speeches', one can possibly find the operative instructions issued to the intellectuals in order to teach them how to fulfil this goal. Mao's words assume the power of performative utterances: first, the intellectuals are required to correct their standpoint (lichang), which should coincide with the Party's single standpoint. This concept is expressed by shifting the subject to whom 'standpoint' is referred from 'the workers engaged in the fields of literature and art' (wenyi gongzuozhe) to the Party itself. 
The shift is somehow concealed with the use of the first person plural pronoun ['We (members of the) Communist Party'(women gongchangdang我们共产党)], indicating that the only possible correct position for the intellectuals is to support the Party's standpoint. Therefore, according to Mao, literature and art are performative tools to obtain the Party's aims.

Austin examines the difference between a statement, typical of constatative utterances of affirmation or announcement of a certain fact or event (in which the truth is taken for granted), and the performative utterance, which has a productive capacity. ${ }^{36}$ Intentional performativity is one of the most distinctive features of Mao's language. The imperative/exhortative or slogan-type patterns frequently used can be considered as sub-components of a speech act. In Mao's speeches, the majority of the sentences are not reducible to the simple production of a sound or phrase which one could judge, using a simplistic binary code, as true or false. A promise or request, for example, is not simply an enunciation, but rather the expression of the utterance that has produced it: sometimes the locutions are performing an act (illocutionary); sometimes they produce a certain effect or result (perlocutionary). In line with the evolutionary-involutionary curve, the question is not 'What to say' but 'How to say what should be said' (the yan), in accordance with the presumption of correctness embedded in the axiomatic harmony between name ( $\mathrm{ming}$ ) and actuality (shi).

Both Yan'an speeches aim at providing a univocal definition of Party directives, and should act like a sort of clarion call to action. Two of the main features of the documents are repetition of lexical items and structural parallelism; these devices can be interpreted as functions of 'performative' power. Many sentences are illocutionary, and the keywords are often following a modal verb such as yao要,yinggai应该, bixu必须(must, should, have to). Modality devices contain a highly performative power and explicitly indicate the expected response. This power is more evident in Mao's style of discourse, especially in Yan'an where the performative language should contribute to the creation of the symbolic capital necessary to consolidate the CCP's position. Performativity is less perceptible in Deng Xiaoping's 1979 strategically balanced and more pragmatic style.

Mao's style is characterized by a highly agitative undertone, while Deng's style appears mostly inclusive. Mao's style derives from his vision of a developmental model based both on mass mobilization and, in1942, on the idea of politicizing (and policing) the intellectuals in order to create a close working relationship with the CCP. Deng Xiaoping strives to confer in his words a performative power, but his speech lacks any illocutionary force. A significant example is the paragraph in which Deng tries to draw a line of continuity with Mao's theory on the workers in the artistic and literary field. Deng clearly uses the first person plural pronoun and a modal verb formulating the expression 'We have to' (Women yao 我们要), followed by verbs and catchphrases, which should lend a performative energy to his utterances, but fail to achieve that result. ${ }^{37}$ Illocutionary utterances are linked to 
their effects in three ways: the certainty of the receiving side, the certainty that the directives and guidelines will be carried out, and the call for an answer. These three features are different from the simple production of effects, typical of performative utterances. As far as the receiving side is concerned, I agree with McDougall who argues that Mao, between the first speech and the conclusion, had 'become more certain of the correctness of his views and the harmfulness of the opposition'. 38

After 1949, the reception of his speeches was guaranteed thanks to the omnipresence of the Propaganda apparatus in charge of the capillary diffusion of the political guidelines. Concerning the certainty of implementation, the Yan'an speeches became the benchmark of the Chinese system of art and literary control for thirty-four years. Evidence of their efficacy as a call to action is the fact that many writers after Yan'an tried to correctly implement Mao's guidelines; the clearest example is the case of Zhao Shuli' s 1943 short story 'The marriage of Xiaoerhei' (Xiaoerhei jiehun小二黑结婚). ${ }^{39}$

\section{Propaganda: agitation and integration}

Mao's and Deng's speeches use similar contrastive techniques, with a particular emphasis on antithetic categories such as 'old' and 'new', 'past' and 'present'. Nevertheless, the symbolic value and the connotation of these adjectives are very different, as a consequence of the differing historical periods.

The use of contrastive analysis in Deng's speech can be epitomized in the expression 'weed through the old to bring forth the new' (tuichen chuxin推陈出新). This expression sounds ambiguous in the 'new historical period of socialism' (shehuizhuyi xinde lishishiqi 社会主义新的历史时期). $4^{\circ}$ Deng Xiaoping, on the one hand, intends to claim his continuity with the legacy of the past, namely with Mao's policy towards the intellectuals in the 'seventeen-year period (1949-66)'; while on the other, he strives to set himself and Mao Zedong apart from all the 'mistakes' made in the 'ten years (1966-76)' whose scapegoats are clearly identified in Deng's speech as Lin Biao and the Gang of Four.

In Mao's case, the fundamental idea is 'to make the past serve the present': he clarifies the need to remould the intellectuals and maintain a clear-cut distance from a certain past and incorrect standpoint (lichang), a past attitude (taidu态度), a past audience (gongzuoduixiang工作对象), work (gongzuo工作) and study (xuexi学习). Mao guides the audience by means of simple examples and using a question-answer format; he also applies manichean categories, so that the difference between what is 'new' - associated with 'bright' (guangming光明) - and what is 'old' - associated with 'dark' (hei'an黑暗) becomes clearer and more precise.

The use of dichotomous categories is a characteristic of these speeches, since they both call for change, but the direction of 'change' always ends up implying the intellectuals' 
mobilization to achieve the Party's goals. Therefore, the intellectuals, who are allegedly the subject of these speeches, are in fact the objects, not only because they are the 'receivers' of the speeches, but also because they are explicitly required to perform the actions indicated. The intended direction of 'change' is very different: in Mao's case the 'literary workers' should repudiate the 'old world' and establish a 'new' start towards a 'revolutionary order', while in Deng's case the intellectuals are required to support the 'four modernizations' program. In accordance with the rhetoric style of propaganda and its performative function, the call for change is the leitmotif of the CCP's major political documents, but the precondition of change is the recognition of the absolutely dominant position of the Party, and the full support of its policy.

The undertone of 'change' is also completely different: Mao's style is characterized by the tone and structural devices typical of propaganda of agitation, while Deng's speech shows all the typical features of propaganda of integration. In Mao's case, agitative action and mobilization are meant to produce a change in the intellectual's mindset: this seems to be a reaffirmation of the Confucian value of loyalty (zhong忠), in this case to the Party, in the sense of abiding by the directives and guidelines set by the rulers. In Deng's case, the idea of change assumes the significance of a re-conquered loyalty (after the experience of the Cultural Revolution): the intellectuals are called to aggregate under Deng's aegis and offer full support to the new leadership's modernization drive.

Even though Mao Zedong makes a larger use of linguistic devices typical of the propaganda of agitation, he, at times, skilfully mediates some elements typical of propaganda of integration. His political conception was based on the presupposition that, in order to fulfil a certain aim, it was necessary to make a lever of the 'broad masses' (dazhong), carrying out a general mobilization of the entire nation. The objective was always stated very clearly, even though the method to obtain a certain goal had, most of the time, to be inferred through an analysis of the underlying structure of the language. This is a characteristic of political language which Perry Link defines using the neologism weimubiaozhuyi为目标主义 (solely targetization). ${ }^{41}$ This elusive feature of political language persisted and tended to become even more evident in the post-Mao era, as a consequence of the increasing dichotomy between the words and a claimed reality. A clear example can be found in the two expressions jingshen wuran精神污染(spiritual pollution) used in the 1983-84 political campaign, and jingshenwenming 精神文明 (spiritual civilization) used especially in the Nineties. In these two compound expressions, the meaning of the term jingshen精神 assumes two antithetic connotations, and its real significance essentially derives from the accompanying word (pollution in the first case, civilization in the second). Therefore the whole expression sounds extremely ambiguous and elusive. The term jingshenis one of the keywords of Deng's speech but I would not translate it as 'spirit', rather a 'policy', since it refers to the most suitable policy of the moment. 42 
In Mao's time, the targets of political campaigns were designed according to the political priorities of a specific historical moment. They were expressed by formulas as generic as 'destroy the old social order' (dadao jiushehuizhidu达到旧社会制度) or 'to put art and literary works at the service of the masses' (wei dazhong fuwu为大众服务). The interpretation of these ideas within Mao's hegemonic discourse indicates that the intellectuals should put art and literature in the service of the Party and, finally, of Mao himself. The logocentric model of power enforced by Mao Zedong after Yan'an was based on the correspondence between signifier and signified, and revealed an implicit transitive property based on the syllogism that the $\mathrm{CCP}$ is the avant-garde of the proletariat and Mao is the leader-màximo of the CCP.

The aim of a political campaign was usually expressed by a syntagmatic unit (like weidazhongfuwu为大众服务), mostly in a four-character form and often including a numerical component. These devices show a high degree of mimetic value while having a semiotic value within the CCP totalitarian discursive strategy. The CCP has always been on the alert for ways to provide succinct expressions for the public: four-character expressions are easy to memorize since the structure is exactly the same as traditional Chinese set phrases (chengyu成语), proverbs (yanyu浐语), and rhymed couplets (duilian对联).

The use of numbers might create a problem of intelligibility to outside readers --since no specific references are made to the connotation of the number + Noun/Verb pattern- but it is always a matter of language in context: during the Cultural Revolution, for example, everybody knew what the two antithetic expressions 'five red categories' (hong wulei红五 类) and 'five black categories' (heiwulei黑五类) were referring to. 43

Numeric rhetorical tropes have often been used to epitomize and condense Party directives, more or less complicated and/or controversial ideological concepts, top leaders pronouncements or entire political campaigns. In the new, simple and condensed numerical form, these 'ideas' are ready to be memorized and quoted by everyone, no matter the degree of literacy of the receiver. These devices enable the speaker to reduce the complexity of political issues into a simple dichotomy between pre-defined (and absolutely correct) 'right' and 'wrong' categories. At the same time, the proper use of these four-characters and numerical expressions may be utilized to evaluate the political orthoproxy of individuals.

Three and four are favourite numbers; in the post-Mao era, the numeric rhetoric has not disappeared, but it is inscribed within Deng's call for the intellectuals to support the Party in the 'four modernizations' (四个现代化or sihua四化) drive. All the socio-political campaigns of the post-Mao era (including Jiang Zemin's era 'three stresses' - sanjiang 53 三 讲-and'three representatives'- sange daibiao三个代表 $)^{44}$ can be considered parts of a major project: the realization of the policy of 'opening and reform' (gaige kaifang改革开放), whose success is the sine qua non for the CCP's preservation of power and socio-political stability. 
Deng Xiaoping's political strategy consists in a broad and strategic use of the tools of propaganda of integration. Deng's words reveal an overt attempt to include the 'rehabilitated' (pingfan平反or zhaoxue昭雪) intellectuals in the category of the working class, but his final aim is to convince them to trust and be loyal to the new leadership. Deng asks the intellectuals to put their skills and expertise to the service of the nation since this is a fundamental asset and a tool to consolidate his personal victory. Deng's inclusive strategy takes for granted the intellectuals' support for the cause of 'modernization'. He insists that this is the intellectuals' responsibility (zeren 责任): 'to achieve the common target of the four modernizations'; the verb to achieve (shixian 实现) is a perfomative verb with a pragmatic force since it carries the connotation of 'making real here and now'. The use of common (gongtong共同) is part of the strategy of showing as a shared value what is, in reality, Deng's final aim.

Deng uses more than once the adverb tongyintongdede同音同德的 (to be of one heart and one mind), which carries a strong ethical connotation associated with a commendatory tone. This adverb expresses an idea similar to another slogan typical of the early Deng era: quanxinquanyi gao sihua全心全意搞四化(whole-heartedly achieve the four modernizations). Deng tries to capitalize on the traditional duty assigned to the intellectuals to be concerned about public affairs, which was based on an ascribed ethical sense of double responsibility towards the ruler and towards the people. 45 But Deng's ambiguity is revealed by the expression 'develop the ethic of the prevailing custom' (peiyang daode fengshang培养道德风尚), which clearly refers to the 'mandate of the Party' (dangxing). Deng also strives to emphasize the continuity with Mao's premises: he argues that 'Our literature and art belong to the people' (Womendewenyi shuyu renmin我们的文 艺属于人民), using the all-inclusive plural pronoun while paraphrasing Mao's famous slogan. Deng's attempt to rely on Mao's legacy is made even more explicit: 'We must continue to sustain the direction-policy raised by Comrade Mao Zedong stating that literature and art must serve the largest masses of people(wenyi wei zuiguangda renmin qunzhong文艺为最广大人民群众), first of all the peasants-workers-soldiers.' 46 The asymmetry with Deng consists in his idea that the intellectuals must be considered part of the working class, while in Mao's speeches the term 'intellectuals' (zhishifenzi) mainly has a derogatory tone associated with the 'petit bourgeoisie' (xiaozichanjieji资产阶级). For Mao, the high level of integration existing between workers-peasants-soldiers (gongnongbing工农兵) and, conversely, the exclusion of the 'workers engaged in the fields of literature and art' (wenyigongzuozhe) are irrefutable axioms. The first group was classified as renmin (people人民), while the second one was more or less explicitly considered as feirenmin (non-people非人民), and necessarily bound to be criticized and remoulded. Mao offers an example from his personal experience describing how he realized, changed (bianhua变化) and corrected (gaizao改造) his misconception about the 'dirty' (zang脏) peasants and the 'clean' (ganjing干净) intellectuals: 'I can tell you 
something from my personal experience on the transformation of my feelings' 47 and concludes: '[...] I came to realize that, compared with the workers and the peasants, the un-remoulded intellectuals were not clean [...].'48 In the following passage, Mao uses the all-inclusive plural pronoun (women) to state his conclusion by means of a doublenegative parallel rhetorical sentence:

If our writers and artists, who come from the (bourgeois) intelligentsia, want their works to be received by the masses, they must change and remould their thinking and their feelings. If there isn't such a change, such a remoulding, they cannot do anything well and will be misfits. (我们知识分子出生的文艺工作者, 要是自己的作品为群众所欢迎, 就得把自己的思想感情来一个变化, 来一番改造.没有这个变化, 没有这个改造 什么事情都 是做不好, 都是格格不入的). 49

Mao's statement is actually based on a disingenuous simulation, because the real problem is the acceptance/absorption of the intellectuals by the Party, not by the masses. Using the double negation pattern, Mao stresses the necessity to remould the intellectuals: the keyword is 'change' (bianhua), which for Mao has an internal and psychological connotation while the same term, used by Deng Xiaoping or Jiang Zemin, carries a more external significance. In combination with bianhua, Mao uses the modal verb yao要 (need/have to) and the adverb jiu就. Jiu is not translated into English, but acts like a diexis, carrying a pragmatic force and leading the receiver to the inevitable conclusion that remoulding is the sine qua non to be considered 'correct' and therefore accepted by the Party.

The double negative structure meiyou没有...meiyou没有indicates the total negation of any real way-out, unless the intellectuals support the Party line. The syntactic structure of this passage is meant to strengthen the rejection of any possible attempt to refute Mao's words: the double negation confers a sense of absoluteness to Mao's words. In political language, axiomatic principles are often expressed by means of a symmetric double negative structure: a typical example is the famous song called 'Without the Communist Party there can be no new China' (Meiyou gongchandang, jiu meiyou xinzhongguo没有共 产党, 就没有新中国). Another example of this structural pattern can be found in Mao's speeches, when he refutes the possible existence of abstract 'love':'In this world there is absolutely nothing like love without cause norreason (shishang juemeiyou wuyuanwugude ai世上绝没有无缘无故的爱),and there is no hate without cause nor reason (ye meiyou wuyuanwugude hen也没有无缘无故的恨), we cannot love our enemies, we cannot love the ugly phenomena of the society (women buneng ai diren, buneng ai shehuide chouloude xianxiang我们不能爱敌人, 不能爱社会的丑唡的现象) ... our aim is to make these kind of things perish and disappear (womende mudi shi xiaomiezhexie dongxi 我们的目标是消灭这些东西)'. 50

The different connotation of the keyword 'change' in Mao's and Deng's speeches could also be interpreted as if Deng Xiaoping wanted to imply that, thanks to the efforts of the 
Party in the Maoist era, the 'petit bourgeois intellectuals' have finally been successfully remoulded: they have accomplished their duty, their thoughts and feelings have become 'clean' and 'correct', so now, in the 'new period', the intellectuals are part of the working class. The completion theme of the remoulding process is also implicit in the speeches given by Jiang Zemin on the intellectuals: Jiang strives to show a similarity in the respective visions of Mao and Deng, and often uses the new expression 'advanced intellectuals' (xianjinde zhishifenzi先进的知识分子) as if the remoulding had already been successfully completed and new intellectuals had emerged. ${ }^{51}$

\section{The socio-political implications of grammar}

Language is something alive: if a strict relation exists between language and politics, a parallel and intertwining relation exists between language and society. A specific language is both a precondition for a certain form of social life and a key instrument in the definition of socialization's forms. In discursive regimes, however, the understanding of formalized language implies a logical analysis of the evolutionary relation between names and things. In political documents, language often assumes a performative rather than constatative force, and is therefore connected with promptings to act. Language acts in and on the organization of thoughts, feelings and communication; in any language semantics ${ }^{2}$, syntactics 53 and pragmatics, ${ }^{54}$ have a specific socio-political nature. ${ }^{55}$ The predominance of a certain grammatical structure implies a previous choice made by the speaker, who has to take into consideration the impact of a wide range of psychological and social factors on the possible achievement of an ideal symbiotic relation between the emic view of the speaker's discourse (his value system), the comprehension and belief in the listener's ability to absorb the implicit message, and a potential capacity to foresee the possible reaction of the audience. Reaching a harmonious relation between these three components is essential to achieve the intended goal of the author. Therefore, grammar in usage has intentional rather than preterintentional functions, and every language consists of a defined set of patterns (basic schemata or syntagmatic models) and combination rules which define the interrelation between specific 'names' and the relevant 'actualities'. Grammatical rules have a precise role in connecting lexical items and conveying a certain meaning, making ourselves understood in a certain way instead of another. Bringing this idea to its extreme consequences, Kress and Hodge argue that 'every rule of grammar is a social prescription, a form through which ideology is transmitted'..$^{6}$

The grammatical structure of language has a socio-political significance which reveals its real essence. As Hans Georg Gadamer states: 'Thanks to the linguistic nature of all interpretation, every interpretation includes the possibility of a relationship with others. 
There can be no speech that does not bind the speaker and the person's contexts and symbols. ${ }^{57}$ This is also true in the Chinese case where the pragmalinguistic approach ${ }^{58}$, which deals with the context that is formally encoded in the inner structure of the language, is particularly suitable to reveal the interrelation between intratextual features (sentence patterns, cohesive ties, etc.), pretextual (the views of the writer and the reader) and contextual factors (the social and cultural environment).

\section{Deconstructing political language: repetition}

One of the main features of Mao's and Deng's speeches is repetition: this is typical of political communication since repetition has both the pragmatic force of successfully conveying the intended meaning of the message and a cohesive function. Repetition is a dual phenomenon: repetition of lexical items (e.g. same word or very similar expressions) on the one hand, and repetition of sentence patterns (with identical syntactical structure) on the other.

Repetition of the same lexical items is extensively used throughout the texts: the same keywords appear in the subject/object position in different sentences. Repetition of the same words and frequent use of coordination sentences seem to denote a high level of generality or lack of depth, but this phenomenon is intentional for at least two reasons. First, from an objective perspective, in 1942 the level of literacy and education was extremely low and, even though the diffusion of education witnessed significant improvements (especially in the period 1949-66), the average level of literacy was still low in 1979.59

Strategically, where a few fundamental words are repeated over and over, they can be learnt by heart and sediment in the receivers' mind. Second, from the subjective perspective, the use of repetition is a powerful tactical tool of hegemonic discourse, typical of brainstorming techniques. It is also important to remember that in Mao's China the propaganda apparatus often used loudspeakers. ${ }^{62}$ Listening is different from reading: if one is listening to a speech, one cannot go back to the previous paragraph and read it again, therefore the key concepts must be repeated over and over to be sure that they are heard, absorbed and memorized by the listeners.

Repetition, especially in Mao's case, is accompanied by the use of coordinate clauses and rhetorical questions. If one considers the author's language as an indication of the maturity level of development of the producer, one would be tempted to conclude that the writer is a child. In fact, the repeated use of coordination is typical of children's writing and writing for children, but the authors of these speeches are skilful politicians. It is evident, therefore, that the use of this kind of language is intentional. It is aimed at leading the 
receiver by hand (as if he was a child): this technique positions the speaker and the receiver on the same level while, at the same time, implicitly reaffirms the speaker's higher degree of experience. This kind of language aims at creating a climate of reciprocal trust: the receiver can trust the speaker who poses the questions and asks him to ponder the situation, but the receiver already knows that the answer will be offered to him, and is led to unconsciously accept that answer as reassuring and 'correct'.

Repetition is an effective mnemonic device: it helps the receiver to accept and memorize certain ideas, when they are expressed using the same lexical items and reinforced by codified grammatical patterns. Repetition brings into existence a visual syntax of a claimed reality. In Mao's speeches, the main clauses that remain inculcated in the receiver's mind are the following three: jiefang sixiang解放思想(emancipate the mind), shishiqiushi 实事 求是(to search truth in the facts), and wenyi ...wei renmin fuwu文艺...为人民服务 (literature and art to serve the people).

It is more difficult to enucleate a few repeated words or clauses in Deng's speech. The opening of Deng's speech seems to follow the same scheme and subdivision of Mao's speeches, but then it reveals a less organized and consequential pattern. The first two paragraphs are followed by a long section clearly aimed at legitimizing Deng's and the Party's policy towards the intellectuals, as if this were the normal consequence of the 'correct' policy of the first 'seventeen years' (1949-66), disrupted by the Cultural Revolution and the mistakes of Lin Biao and the Gang of Four. Deng's speech is fundamentally based on the antagonist vision between past and present, but it also shows the intention to draw a line of continuity between the present situation and a certain representation of the past, accurately selected, and strategically reinterpreted using the abovementioned three key concepts of Mao's speeches, but with a completely different connotation. The final result is ambiguous: with this speech Deng Xiaoping creates a range of possibilities rather than stating a definite line. The 'new' keywords of Deng's discourse emerge through the technique of numerical rhetoric and contrastive devices, but they seem to contradict the continuity with Mao's legacy, which Deng strives to claim. The 'new' paroles d'ordre are: sihua四化(four modernizations) and shehuizhuyi xinde lishishiqi社会 主义新的历史时期(or xinshiqi新世纪: new historical period of socialism). Deng tries to connect them with Mao's three key expressions but also add something to them, for example when he argues that 'the people need art but art needs the people even more' (renmin xuyao yishu, yishu geng xuyao renmin人民需要艺术, 艺术更需要人民). ${ }^{60}$

The second kind of repetition refers to the syntactical structure, and can be observed in the frequent use of coordinated sentences consisting of the typical Subject + Verb + Object $(\mathrm{S}+\mathrm{V}+\mathrm{O})$ structure. This feature creates a structural parallelism, which should function as an inner cohesive link between the various parts of the text, and confer a higher degree of internal coherence to the whole text. This device combines two pragmatic forces: the explicit force (that lies on the surface and is unstated) and the implicit force (that is below 
the surface and understated).

The repeated sentence structure can be divided into two patterns. The first one is characterized by the symmetrical paratactic ordering $\mathrm{S}+\mathrm{V}+\mathrm{O}$, leaving the Subject immutable and repeating the Verb, but modifying the Object. Mao's speeches offer various examples of this parallel Subject Predicate sentence pattern, often with the negative form of the Verb, which confers a strong derogatory connotation towards the intellectuals. An emblematic examples is: 'Our workers engaged in the fields of literature and art are not familiar with the workers, are not familiar with the peasants, are not familiar with the military and are not familiar with their cadres(我们的文艺工作者不熟悉工人(S+Neg.V+O), 不熟悉农民,不熟悉士兵,也不熟悉他们的干部).' Mao refers to the target of art and literary work (gongzuo duixiang wenti工作对象问题), and uses this particular technique to emphasize the negative side of these 'workers'. The 'truth' is stated by means of a negative form. The first three parallel sentences $(\mathrm{S}+\mathrm{Neg} . \mathrm{V}+\mathrm{O}$, Neg. $\mathrm{V}+\mathrm{O}$, Neg. $\mathrm{V}+\mathrm{O})$ are coordinated sentences on the same level of generality, while the last one (with the same basic structure) comes as a conclusion, as an afterthought, almost fully independent. Analysing the contrastive pronouns, the final utterance is the interpretive key: at the beginning, the intellectuals are included in the Party by means of the all-inclusive pronoun 'our' (womende), but, in the final part, they are clearly put in a subordinate position, by means of the pronoun 'their' (tamende 他们的), which refers to the cadres of the Party. The key concept is that the intellectuals 'are not familiar with their cadres', and therefore they cannot be considered reliable and functional to the CCP. Here Mao reaches the climax of his speech, identifying the major problem with the intellectuals: their crime lies not so much in the fact that they do not understand the 'people' (the triad gongnongbing), but more so in the fact that they do not understand how the CCP leading cadres want them to express themselves in their works.

This indicates a shift between what apparently are three objects plus one into three objects (gongren工人... nongmin农民... shibing士兵) plus one subject (ganbu干部): according to Mao, the real purpose of art and literature is to lead the peasants, workers and military to think what the Party cadres want them to think. The intellectuals' real duty is to strengthen the correct way of thinking, through the enforcement of a logocentric model of power based on a codified way of expressing themselves, as if their words automatically corresponded to a claimed reality. This pattern can be traced back to the paternalistic idea of Confucian political culture, embodied in the dual concepts of xiao-zhong 孝忠 (filial piety and loyalty) and ren-yi仁义(benevolence and justice), appropriated and re-elaborated by the CCP. CCP leaders, from Yan'an onwards, have often presented themselves, by means of rhetoric pronouncements, as benevolent and as sage father-figures who know the 'correct' behaviour and can explain, for the wellbeing of the people, what is right and wrong. Even in the post-Mao era Mao has been considered by many people as a saint. ${ }^{61}$

The second sentence pattern $\mathrm{S}+\mathrm{V}+\mathrm{O}$ is characterized by the same Verb-Object scheme, 
with a variation of the Object (parallel object) and the frequent use of a multiple Subject, while the Verb remains practically unchanged. Sometimes the same verb is repeated, while other times a synonymous Verb is used, as when Mao states:

\begin{abstract}
The cadres of all types, soldiers in every army, workers in the factories, and peasants in the villages, if they know the characters (i.e. are literate), they all want to read books, read newspapers; if they don't know the characters (are illiterate), they still want to see plays, they want to look at pictures, sing songs and listen to music...(各种干部,各队的战 士,工厂的工人,农村的农民,他们识了字,就要看书、看报,不识字的, ( 他们- implied -)也要 看戏、看画、唱歌、听音乐) ${ }^{6}$
\end{abstract}

In Chinese the dunhao顿号 ( ) or repetition comma is used; it functions as a cohesive tie between the different terms and confers to the whole sentence a precise rhythm.

These are all specular sentences based on the structure $\mathrm{S}+\mathrm{V}+\mathrm{O}$. The climax is reached in the conclusion: They are the receivers of our workers engaged in the fields of literature and art' (Tamen jiu shi women wenyi gongzuozhede jieshouzhe他们就是我们文艺工作者的 接受者). This technique is extremely useful since it clarifies how the intellectuals have to become one with the Party (our) and produce 'words' in line with the new 'reality'.

In Deng's speech, on the contrary, structural parallelism has a decisively inferior importance, and the two fundamental pragmatic forces, implicit and explicit, don't seem to coincide. It becomes difficult to identify the implicit force acting between the source and the target messages and, sometimes, it becomes impossible to believe in the pragmatic effect of equivalence between the two messages. The gap existing between the source and target has become wider, and this widening of the gap is as a consequence of the irresolvable dichotomy between the name (ming) and the actuality (shi). In Deng's case one can see a plurality of forces: the apparent intention of the message contained in Deng's political speeches is not the same as its actual content, and everything becomes more ambiguous.

\title{
Rhetorical questions, connective devices and cohesive ties
}

Rhetorical questions carry an apparent denotation of uncertainty, but the speaker already knows the exact answer, and therefore this technique has an implicit syllogistic connotation of request-order to act accordingly. A clear example is contained in Mao's second Yan'an speech conclusion, when he discredits the heightening (tigao提高) of knowledge and emphasizes the importance of diffusing (puji普及) knowledge among the masses. Like a good father-pedagogue Mao poses the rhetorical question: Yong shenme用 什么? (How? Using what?), before explaining how to diffuse knowledge. This also shows 
that rhetorical questions function as connective devices between different paragraphs of the text. Mao frequently uses parallel rhetorical questions, either at the beginning of a paragraph, or as independent paragraphs, or to introduce the main theme of the whole paragraph. This technique is useful in emphasizing central ideas more effectively, and holding a big part of the text together.

This leads to the question of convergences and divergences between the grammatical structures of Mao's and Deng's texts. Mao makes extensive use of very simple, fully understandable examples, often linked to his personal life experience. He also uses rhetorical questions to link the various paragraphs of his speech, giving a sense of structural cohesion and coherence to the whole text. The overall result is that his speeches appear much less pragmatic or schematic than those of Deng Xiaoping or Jiang Zemin. Deng often uses quotations and paraphrases, which show the intention to claim continuity with the previous leaders in cultural matters, but ultimately betray his interest in demonstrating the legitimacy of his own position of power. Jiang Zemin's 'style' is more slogan-like and strives to emphasize a common understanding of the role of intellectuals from 1949 onwards. ${ }^{63}$ Different techniques are used in different texts as they are meant to achieve different results. In Deng's speech, a recurrent cohesive device is the expression 'the new historical period': this refers to his own era, but the xin (新new) echoes the xin (new) of 'Mao's style' expression 'new China' (xinzhongguo新中国), and tries to confer legitimacy to Deng's position. Nevertheless Deng's attempt to demonstrate the continuity between the Party's policy towards the intellectuals in the 'new period' and the CCP policy before the Cultural Revolution remains ambiguous. The difficulty of advocating this standpoint is reflected in Deng's language: the whole speech is full of generic and ambiguous, sometimes even contradictory expressions. The clearest example is the following statement: 'During the seventeen years before the Great Cultural Revolution, our literary and artistic line has been basically correct (jibenshang shi zhunquede基本上是准确 的), the achievements of the workers engaged in the fields of literature and art have been remarkable.' ${ }^{64}$ The whole passage sounds ambiguous, since the degree of certainty in Deng's argument is invalidated by the use of the adverb jibenshang基本上(basically)in the first sentence. Jibenshang assumes an ironically antithetical connotation when associated with zhunque准确(correct), especially when the idea of correctness is historically contextualized, and associated with Confucius zhengming theory. Here the attempt to argue that the Party line on literature and art (and therefore the policy towards the intellectuals) has been 'fundamentally correct' (jibenshang shi zhengque) is followed by the extremely vague and elusive statement 'the achievements ... have been remarkable.' In the restricted code of political language, the ambiguous expression jibenshang zhunque not only means 'not completely' (the opposite of wanquan 完全meaning 'completely'), but leads the receiver to infer that the policy was 'absolutely not correct', and wonder what kind of 'remarkable achievements' Deng Xiaoping is referring to. ${ }^{65}$ 
Exhortative expressions and $b a$ type sentences represent two other features typical of these speeches, and they are also clear examples of cohesive ties. The $b a$ 把form is a recurrent formula associated with agitation propaganda. When it is clearly expressed, the $b a$ 把form can reveal a political campaign in an ascending phase or in a more emphatic resumption trend. The $b a$ 把particle, especially when it is part of the final sentence and therefore positioned at the end of text, has the function of winding up a political campaign: it draws a certain inevitable conclusion and indicates a request, which is expressed more in the form of a call to action than in an explicit commendatory tone. These kinds of exhortative/imperative devices are meant to excite the sentiments of the people: they are typical of oral speeches, but are also frequently used in political slogans and posters, functioning as powerful epitomes of the 'speech acts' represented by the CCP's key political documents. ${ }^{66}$ Therefore, a prerequisite of success for a political document is that it must contain a few fundamental sentences, such as, in Mao's speeches, the expression 'literature and art must serve the people' (wenyi wei renmin fuwu). These key sentences can be distilled in slogans easy to memorize.

\section{Conclusion}

Prasenjit Duara argues: 'Language as an arena of historical contest is where we may witness the historicity of History'. ${ }^{67}$ This article provides a study of language and political discourse in modern China by focusing on the ways in which Mao Zedong and Deng Xiaoping, respectively, have attempted to codify cultural practices and shape language in order to create intellectual discourses within the framework of a specific social and political order.

76 I have analyzed, through political language, two symmetrical but partially antithetic key events in Chinese history: the consolidation of Mao's political and cultural power in the cradle of the communist revolution in Yan'an (1942) and Deng Xiaoping's affirmation of power in the cultural-political sphere in 1979. My aim was to provide a better understanding of: 1. CCP's expectations from the intellectuals engaged in the artisticliterary field; 2. the relation between the mechanisms of production and reception of formalized political language.

The selected speeches show similarities but also significant differences, which I defined using the parameters of symmetry and asymmetry, within the conceptual framework of a curve delineating a process of evolution-involution-devolution of the relation between names and actualities.

Review of the evidence contained in these documents reveals that the expressions used in these speeches, the conjunctions and interactions of particular syntactical or semantic devices, discursive rules and pragmatic techniques are intentional. 
My focus is on written political documents adapted from oral speeches since I agree with Jacques Derrida that writing (traces, as he says) is the beginning of everything. ${ }^{68}$ This is particularly relevant in the Chinese case, dominated for centuries by the axiomatic unity of writing and power: wen 文indicates both the written language and the functional essence of the civil servant who was entitled to perform his duties only if he had acquired the ability to master the literary texts (dushu zuoguan读书做官), containing the 'correct' patterns of representation of a claimed reality. In Imperial China the discernment of writing was the only way to be part of the organizational structure of political power.

Under Mao, the authoritarianism of a newly formalized language contains a high potential for alignment, absorption and internalization, and constitutes one of the most effective devices to set boundaries in the people's range of re-presentation of the 'real' world. Mao's Yan'an speeches combine an assertive tone, a simple and direct style, and the use of coordinative sentences linked by cohesive ties: their aim is to exhibit the highest possible degree of coherence and avoid any dubious remark, which might confuse the receiver. Thanks to a precise syntactic structure and a standardized repetitive pattern, the key concepts can directly reach the receivers expecting them to act accordingly. The reiteration of formalized sentence and grammar patterns through the media succeeded in creating a more or less fictitious image of a one-sided reality, based on the presumption of the annihilation of any possible dichotomy between surface and underlying structures of names (ming) and actuality (shi) by means of 'correct' and codified 'sayings' (yan). Mao's political speeches had both a paternalistic tone and a performative force. Slogans, four-character political sayings and key words revealed an implicit and absolute directive to prevent a priori any possible emergence of heterodox forms of expressing personal feelings and ideas. The centuries old socio-psychological mechanism of Confucian-style role modelling combined with CCP style intellectuals' remoulding and, last but not least, emotional internalization of a prescribed unilateral form of expression, demonstrated all their effectiveness during the Cultural Revolution (1966-69). During that period ${ }^{69}$ the alignment with the only authorized expressive code (both visually and verbally) reached its climax (but also its first point of no-return) as is evidenced by examining the case of the 'docile bodies' of Chinese intellectuals ${ }^{70}$, which fully shows the efficacy of the inversionary discourse.

In the post-Mao era, the master narrative of political language is the story of a progressive and unstoppable devolution due to an inexorable detachment between the 'name' (ming) and the 'actuality' (shi) via the dissolution of the 'saying' (yan). The gap between ming and shi and the impossibility of the yan to hold them together has opened new possibilities of pursuing subjective discursive practices. Distinguished voices have emerged in the artistic and literary fields, where intellectuals have experimented language disruptions, polylinguality, scattered words and phrases, alternative forms of narrative, disjunction, fragmentation and even fractured characters as in the case of the artwork of 
$\mathrm{Xu}$ Bing..$^{71}$ The deconstruction of language is a fundamental element in his artwork: $\mathrm{Xu}$ Bing investigates the creation of language, how it is learned, the barriers and structures it creates, and the meaning and non-meaning of the written word. Xu Bing is well known as the inventor of thousands of 'characters-non-characters' inscribed in the 'Book from the Sky (Tianshu天书)' (1991), which represents the most significant example of language-based artwork. These signs, reinvented by the artist, look like authentic characters although they are absolutely unintelligible. In another artwork, 'Chairman Mao said: Art for the people', $\mathrm{Xu}$ Bing emphasizes with his own interpretation and understanding the famous Maoist ideological position on art and literature at Yan'an. In another installation, the 'Living Word' (2001), Xu Bing goes one step further, exploring the transformation of English and Chinese scripts: this work shows Xu's invention of a new written language through the example of intertwining bird shapes.

These creative phenomena can be interpreted as signs of the urge for demystification of the formalized language that is characterized by a widening and unsolvable gap between the name (ming) and the actuality (shi), due to the dissolution of any possible connection between the political saying (yan) and the symbolic order of representation of reality.

\section{Notes}

1 Confucius, The Analects (Lunyu), Book XIII, Chapter 3. http://www.afpc.asso.fr/wengu /wg/wengu.php?l=Lunyu\&no=320. Accessed 10/12/2008. See also: James Legge, The Chinese Classics, With a Translation, Critical and Exegetical Notes, Prolegomena, and Copious Indexes, in five volumes, Hong Kong, Hong Kong University Press, 1960. Reprinted [1893-95]), and in particular vol. 1, 1861, available also on line at: http://nothingistic.org/library/confucius/analects/toc.html

2 In biological science, the term is associated with the theory of phylogeny, which argues for the origin of different plants and animals in other pre-existing types, and their progressive modification in successive generations.

3 In the sense of a study of a theory of the nature and ground of knowledge (and in this case political knowledge), especially with reference to its limits and validity.

4 Jacques Lacan, Ecrits, London, Routledge, 2001 (Trans. Alan Sheridan). The idea of 'claimed reality' refers to the virtual symbolic order, what Jacques Lacan called 'big Other', which is the dominant political, cultural and mainstream media network that structures reality for us.

5 Confucius, The Analects, Book XIII, Chapter 3. http://www.afpc.asso.fr/wengu /wg/wengu.php?l=Lunyu\&no=320 Accessed 11/12/2008.

6 Language is not merely a medium of communication but embodies an actual action as well. J. L. Austin introduced the notion of 'performative utterances': utterances which not only state that you intend to do something, but actually do that thing as a result of being spoken (for ex. a justice of peace uttering I now pronounce you husband and wife creates de facto a legal union). John L Austin, How to do Things with Words, New York, Oxford University Press, 1962.

7 Confucius, The Analects, Book XII, Chapter 17. http://www.afpc.asso.fr/wengu /wg/wengu.php?l=Lunyu\&no=310 Accessed 11/12/2008. 
8 Steven Pinker, Language Instinct, Harmondsworth, Penguin Books, 1994, p. 17.

9 Pierre Bourdieu, Language and Symbolic Power, Cambridge, Harvard University Press, 1991, pp. 66-89.

10 Ludwig Wittgenstein, Philosophical Investigations, Oxford, Blackwell, 1953, p. 220.

11 Ibid.

12 Ludwig Wittgenstein, Tractatus Logico-Philosophicus, London, Routledge, 1961, pp. 14-15. Trans. David Pears and Brian McGuinness.

13 I prefer to use 'speech' instead of 'talk' since these documents maintain all the typical characteristics of oral speeches. Mao Zedong, 'Speeches at the Yan'an Forum on Literature and Art' (Zai Yan'an wenyi zuotanhuishangde jianghua), 2 and 23 May 1942, In Mao Zedong, Mao Zedong XuanjiDisanjuan (Selected Work of Mao Zedong), vol. III, Beijing, Renmin Chubanshe, 1991, pp.847-879.

14 Deng Xiaoping, 'Greeting words to the Fourth Congress of Chinese literary and art workers' (Zai Zhongguo wenxueyishu gongzuozhe disici daibiaodahuishang de zhuci), 13 October 1979, In Deng, Xiaoping, Deng Xiaoping WenxuanDierjuan (Selected Works of Deng Xiaoping, Vol. II), Beijing, Renmin Chubanshe, 1983, 207-214.

15 Zhongguo jindaishilan中国近代史览1894-1999 (CD-Rom).

16 I borrow this concept from Foucault and apply it to Liu Shaoqi's theory on the personal aspirations of Communist Party members seen as 'docile tools' (xunfu gongjulun). This concept was first expressed in his 8 July 1937 speech at the Yan'an Marxism-Leninism Institute and then reasserted in a meeting organised by the Beijing Ribao on 30th June 1958 (see: Beijing Ribao's editorial 29 July 1958). Even though during the Cultural Revolution, this theory as expressed by Liu Shaoqi was condemned as a 'negative example', the apparent critique was merely meant to provide a more precise definition of this idea and aimed at indicating the intellectuals' function to serve as 'docile bodies' in the implementation of Mao's 'correct line' as opposed to the 'revisionist' one. See: Michael Foucault, Discipline and Punish: The Birth of the Prison, New York, Vintage Books, 1977, pp. 135-169. Liu Shaoqi 'Lun gongchandangyuan de xiuyang' (On the self-cultivation of Chinese Communist Party members), 8 July 1939. In Liu shaoqi Xuanji (Selected Works of Liu Shaoqi), vol. 1, Beijing, Beijing Renmin Chubanshe, 1949, pp. 97-167; Translated as 'How to Be a Good Communist' In Collected Works of Liu Shao-ch'i, vol. 1, Hong Kong, Union Research Institute, 1969, pp. 151-219.

17 David E. Apter, Tony Saich, Revolutionary Discourse in Mao's Republic, Cambridge, Harvard University Press, 1994, p. 99.

18 Ibid.

19 See: Wei Jingsheng, The Courage to Stand Alone: Letters from Prison and Other Writings, New York, Viking, 1997; James D. Seymour, The Fifth Modernization: China's Human Rights Movement, 1978-1979, New York, Human Rights Publishing Group, 1980.

20 Jacques Ellul, Propaganda: The Formation of Men's Attitudes, New York, Vintage Books, 1965, p. 72.

21 Here I am paraphrasing the title of the book by Peter L. Berger and Thomas Luckmann. The Social Construction of Reality: A Treatise in the Sociology of Knowledge, Garden City (NY), Anchor Books, 1966.

22 L. Wittgenstein, Tractatus, pp. 5-6.

23 Habitus for Bourdieuis a system of practical knowledge, acquired over time, which creates in the social agents the tendency to perceive, act, and react with a certain naturalness within a specific social 
universe, without any need to be coordinated or governed by rules. See: Pierre Bourdieu, Distinction: a Social Critique of the Judgment of Taste, London, Routledge, 1984; Pierre Bourdieu, The Field of Cultural Production, New York, Columbia University Press, 1993.

24 Martin Heidegger, Being and Time, New York, Harper \& Row, 1962.

25 Benedict Anderson, Imagined Communities, London, Verso Books, 1991, pp. 6-7.

26 This axiomatic procedure of derogatory attribution is evident in the political language used after the repression of the 1989 students' movement, when the two terms of shaoshu and fangemingfenzi were frequently associated in the official documents.

27 Dangxing is usually translated as 'Party style' but my translation suggests this as a modern version of the mandate of heaven(tianming).

28 Jiang Zemin, Jiang Zemin lun shehuizhuyi jingsheng wenming jianshe (Jiang Zemin on the construction of spiritual civilization), Beijing, Zhongyang wenxian Chubanshe, 1999, pp. 313-332.

29 See: Carol Lee Hamrin, Timothy Cheek (eds.) China's Establishment Intellectuals, Armonk, M.E. Sharpe, 1986; Merle Goldman, Timothy Cheek, Carol Lee Hamrin (eds.), China's Intellectuals and the State: In Search of a new Relationship, Cambridge (Mass.), Harvard Council on East Asian Studies, 1987.

30 Gao Xingjian made a remark on this point during his talk at Harvard University on Feb. 27, 2001. He emphasized that in his 2000 novel Lingshan (Soul Mountain) he never uses the personal pronoun ' $W o$ ' but only $n i$ and $t a$ (both masculine and feminine forms) as he strongly felt the suppression of the category of personal. Gao Xingian, Soul Mountain, New York, HaperCollins, 2000.

31 Aristotle, The Poetics, Cambridge (Mass.), Harvard University Press, 1927. Trans. W. Hamilton Fyfe.

Aristotle, The Politics, Cambridge, (Mass.), Loeb Classical Library, 1932. Trans. H. Rackman.

32 J. Austin, How to do Things with Words. See also: Herbert Fingarette, Confucius-The Secular as Sacred,New York, HarperCollins, 1972; Michael Schoenhals, Doing Things with Words in Chinese Politics: Five Studies, Berkeley, University of California Press, 1992.

33 John Searle, 'Indirect Speech Acts', In P. Cole and J. Morgan (eds.), Syntax and Semantics, New York, Academic Press, 1975.

34 See: Mao Zedong, 'Problems of War and Strategy', 6 November 1938, In Mao Zedong, Selected Works of Mao Tse-tung, Beijing, Foreign Language Press, 1965, vol. 2, pp. 219-235.

35 Mao Zedong, 'Speeches at the Yan'an Forum on Literature and Art', p.848.

36 J. Austin, How to do Things with Words.

37 Deng Xiaoping, 'Greeting words to the Fourth Congress of Chinese literary and art workers', p. 210.

38 Bonnie McDougall, Mao Zedong's 'Talks at the Yan'an Conference on Literature and Art' A Translation of the 1943 Text with Commentary, Ann Arbor, University of Michigan Press, 1980, p. 14.

39 Zhao Shuli, Xiaoerhei jiehun, Huabei, Xinhua Shudian, 1943. See also: Merle Goldman, Leo Ou-fan Lee (eds.) An Intellectual History of Modern China, Cambridge, Cambridge University Press, 2002, pp. 257-58.

40 Deng Xiaoping, 'Greeting words to the Fourth Congress of Chinese literary and art workers', p. 212.

41 Perry Link, 'Baituo jiquanzhuyide yuyan' (Break Away from the Centralized Language), In Gangzhilian Tongxun (Hong Kong Alliance in Support of Democratic Movements of China), 16, pp. 1-4. Also in Banyang Suiji. Taibei, Sanmin Chubanshe, 1999, pp. 17-28. 
42 Maurizio Marinelli, 'The Desire of Power and the Annihilation of Emotions in Chinese Political Language.' Ming Qing Yanjiu, 2003-2004 Napoli, pp. 143-160.

43 The five red categories identified: workers, soldiers, poor peasants, martyrs and communist cadres; while the five black categories identified landlords, rich-farmers, anti-revolutionists, bad-influencers, and right-wingers.

53 On 5 December 1998 Jiang Zemin launched the 'three stresses' campaign allegedly targeting 'leading officials above the county level through criticism, self-criticism and education, with stresses on studying theory, increasing political consciousness, and cultivating healthy trends.'

44 In May 2000 Jiang made an inspection tour to Jiangsu, Zhejiang and Shanghai. In line with his obsession with 'stability above all' (wending yadao yiqie), on the eve of the 11th anniversary of the Tiananmen crackdown, Jiang stressed the future role of the CCP as 'a faithful representative of the requirements in the development of advanced productive forces in China, the orientation of the advanced culture in China, and the fundamental interests of the broadest masses of the people in China.

45 For more on this see Fan Zhongyan, Fan Zhongyan quan ji(Complete Works of Fan Zhongyan), Chengdu, Sichuan Daxue chubanshe, 2002.Yongxian Li; Ronggui Wang(eds.). Fan Zhongyan (989-1052) was the Northern Song Dynasty's prominent statesman and literary figure who clarified how the intellectual was 'the first person to bear hardships and the last one to enjoy comforts' (xian tianxia zhi youeryou, hou tianxia zhi leerle).

46 Deng Xiaoping, 'Greeting words to the Fourth Congress of Chinese literary and art workers', p. 211.

47 Mao Zedong, 'Speeches at the Yan'an Forum on Literature and Art', p.851.

48 Ibid.

49 Mao Zedong, 'Speeches at the Yan'an Forum on Literature and Art, pp. 851-852.

50 Mao Zedong, 'Speeches at the Yan'an Forum on Literature and Art', p. 872.

51 Jiang Zemin, Jiang Zemin lun shehuizhuyi jingsheng wenming jianshe, pp. 313-332.

52 Signs and their relation to the 'outside world'. Semantics, syntactics and pragmatics are the three fundamental constituencies of semiotics.

53 Signs and their relations to the other signs.

54 Signs and their relations to users.

55 See: Bob Hodge, Gunther R. Kress, Language as Ideology,London, New York, Routledge, 1993; Stephen Levinson, Pragmatics, Cambridge, Cambridge University Press, 1983, p. 35.

56 Bob Hodge, Kam Louie, The Politics of Chinese Language and Culture: The Art of Reading Dragons. London, New York, Routledge, 1999, p. 71.

57 Hans Georg Gadamer, Joel C. Weinsheimer, Donald G. Marshall (eds.), Truth and Method, New York,Continuum, 1993, pp. 119-120.

58 This method refers to the study of the pragmatic force of the language used in context, from the viewpoint of linguistic sources.

59 See: Ministry of Education, China [MOE] (2002) “Achievement of eradicating illiteracy”, available at: <http://www.moe.edu.cn/edoas/website18/level3.jsp?tablename=217\&infoid=2820 >; Ministry of Education, China [MOE] (2005) "The success of universal education in China", available at:

http://www.moe.edu.cn/edoas/website18/level3.jsp?tablename=217\&infoid=17116. Both accessed on 12 March 2007. 
62 This was also true, although to a different extent, in Deng's times: when I was studying at Tongji University in 1988-89, loudspeakers were often used to disseminate civic and political information.

6o Deng Xiaoping, 'Greeting words to the Fourth Congress of Chinese literary and art workers', p. 212.

61 See: Geremie R. Barmé, Shades of Mao: The Posthumous Cult of the Great Leader, Armonk (NY), M.E. Sharpe, 1996; G. R. Barmé, In the Red: On Contemporary Chinese Culture, New York, Columbia University Press, 1999.

62 Mao Zedong, 'Speeches at the Yan'an Forum on Literature and Art', p.85o. In Chinese the dunhao (、) or repetition comma is used; it functions as a cohesive tie between the different terms and confers to the whole sentence a precise rhythm.

63 Jiang Zemin,Jiang Zemin lun shehuizhuyijingsheng wenming jianshe, pp. 313-332.

64 Deng Xiaoping, 'Greeting words to the Fourth Congress of Chinese literary and art workers', p. 205.

65 A significant example of those 17 years could be the 'anti-rightist' campaign, launched in May 1957 when Deng Xiaoping himself was Secretary of the Party with the aim to 'lure the snake out of the hole' (yinshe chudong), luring out the intellectuals who had dared to speak against the Party during the 'double flower' movement.

66 Maurizio Marinelli, 'The Desire of Power and the Annihilation of Emotions in Chinese Political language', pp. 143-160.

67 Prasenjit Duara, Rescuing History from the Nation, Chicago, University of Chicago Press, 1995, p. 235 .

68 Jacques Derrida,De la grammatologie, Paris, Editions de Minuit, 1967 ; Jacques Derrida,L'écriture et la difference, Paris, Le Seuil, 1979.

69 Merle Goldman, China's Intellectuals: Advise and Dissent, Cambridge, Harvard University Press, 1981, pp. 117-55.

70 The literature on intellectuals during the Cultural Revolution is extremely wide. In the Nineties, one could argue that many intellectuals progressively became 'strategic bodies' as opposed to 'docile bodies'.

71 See: Britta Erickson, The Art of Xu Bing: Words without Meaning, Meaning without Words (Asian Art \& Culture), Seattle, University of Washington Press, 2001; Jerome Silbergeld, Dora C.Y. Ching (eds.), Persistence/Transformation: Text as Image in the Art of Xu Bing,Princeton, Princeton University Press, 2006; Xu Bing, Cai Guoqiang, , Where Heaven \& Earth Meet: The Art of Xu Bing and Cai Guo-Qiang, Timezone 8, 2005.

\section{Pour citer cet article}

Référence électronique

Maurizio Marinelli, « Names and Reality in Mao Zedong's Political Discourse on Intellectuals », Transtext(e)s Transcultures 跨文本跨文化 [En ligne], 5 | 2009, document 5, mis en ligne le 03 avril 2010, Consulté le 08 avril 2010. URL : http://transtexts.revues.org/index268.html

\section{Auteur}

\section{Maurizio Marinelli}


Articles du même auteur

Self-portrait in a Convex Mirror: Colonial Italy Reflects on Tianjin [Texte intégral]

Paru dans Transtext(e)s Transcultures 跨文本跨文化, 3|2007

\section{Droits d'auteur}

(C) Tous droits réservés 